\title{
Subacute Toxicity of Brown Truffle (Terfezia claveryi) on Sprague-Dawley Rats
}

\author{
Kanabi M. Rebin ${ }^{1}$, Hiewa O. Dyary ${ }^{1}$, Mahmud R. Harseen ${ }^{1}$, Sharif O. Rozha ${ }^{3}$, Ali H. Hassan ${ }^{2}$ \\ ${ }^{1}$ Department of Basic Sciences, ${ }^{2}$ Department of Anatomy and Histopathology, College of Veterinary Medicine, ${ }^{3}$ \\ Department of Anatomy, College of Medicine, University of Sulaimani, New Sulaimani, Street 27, Sulaymaniyah, \\ Kurdistan Region, Iraq
}

\begin{abstract}
Brown truffle (Terfezia claveryi) is a wild fungi species collected and consumed by humans in Iraq, especially during the raining season, from February to April. However, the toxicological effects of this fungus have not been studied in humans. This study tested the subacute toxicity of brown truffle's methanolic extract on a rat model. Daily oral doses of 200,400 , and $800 \mathrm{mg} / \mathrm{kg}$ were administered to adult Sprague-Dawley rat groups of both sexes for 14 days. There were no behavioral changes, no alterations in body weight, organ weight, and body weight gain $(\mathrm{p}>0.05)$ in the treated rats, compared to the untreated control group. The hematological and serum biochemical parameters did not show significant $(p>0.05)$ differences from the control. Microscopic examinations of the brain, lungs, liver, spleen, kidney, and heart tissues revealed no pathological lesions in treated rats' organs. These results imply that the administration of methanolic extract of $\mathrm{T}$. claveryi to rats does not result in observable toxicity.
\end{abstract}

\section{Keywords: Subacute toxicity, serum biochemistry, Sprague-Dawley rats, Terfezia claveryi.}

\section{Introduction}

Truffles are the subterranean fruiting parts of wild fungi that grow naturally under the ground without human intervention (1). They form ectendomycorrhizal symbiotic associations with plants of the Helianthemum genus (2). Truffles are considered mushrooms due to their spore-forming characteristics. Desert truffles are a type of obligate hypogeous ascomycete fungi that belong to the Terfezia, Tirmania, and Picoa species. They are distributed naturally from North Africa to the Middle East. Two species of dark-brown-color truffles (Terfezia claveryi and Terfezia boudieri) and one species of white-color truffles (Tirmania nivea) are found in the Arabian Peninsula (3). Terfezia claveryi is a common species that grows in the central, southern, and western parts of Iraq (4).

*Correspondence: dyary.othman@univsul.edu.iq

Department of Basic Sciences, College of Medicine, University of Sulaimani, New Sulaimani, Street 27, Sulaymaniyah, Kurdistan Region, Iraq. Received:1 September 2020, Accepted: 4 October 2020, Published: 28 December 2020.

This article is an open access article under the terms and conditions of the Creative Commons Attribution License (CC BY 04 https://crerativecommons.org/licenses/by/4.0).
Truffles grow naturally in large quantities in Iraq in the raining season, between February and April. They are collected from the desert areas and brought to the local markets for sale. Truffles are considered an expensive delicacy. However, during the high season, the consumption of truffles increases drastically by Iraqi citizens because of their availability in large quantities, which leads to reduced prices in the local markets. People in the Middle East are considered the primary consumers of truffles, and their popularity arises from peoples' belief that they have good taste and high nutritional values (5). In April 2019, several poisoning cases by truffle were reported by the Directorate of Health in Erbil, northern Iraq. People were brought to the emergency room with symptoms of poisoning. The patients reported that they had consumed truffles purchased from the local markets, local media conveyed. These reports raised the question about how safe these wild fungi are for human use. According to our knowledge, there are no controlled studies about truffles' toxicities in humans or laboratory animals. Hence, this study was conducted to evaluate the toxicological properties of common brown-color truffle ( $T$. claveryi) by assessing the subacute toxicity using a Sprague-Dawley rat model. 


\section{Materials and Methods}

\section{Preparation of Terfezia claveryi methanolic extract}

Fresh $T$. claveryi was bought from a local market in Sulaimani province-northern Iraq. The fungus was authenticated by specialized personnel at the College of Agricultural Engineering Sciences/ University of Sulaimani.

The truffles were cleaned from debris and imperfections, washed with water, and mashed using a laboratory grinder. Later, an amount of the ground truffles was mixed with methanol (Fisher Chemical, USA) at a ratio of $1: 10(\mathrm{w} / \mathrm{v})$. The mixture was then continuously shaken in a laboratory shaker for one hour, followed by filtering with surgical gauze and filter paper (Whatman no. 4). The filtrate was then put in a rotary evaporator to remove the solvent at $42^{\circ} \mathrm{C}$. The extract was stored in a tightly-sealed glass container at $-20^{\circ} \mathrm{C}$ before using it in the experiment.

\section{Laboratory animals}

Twenty-four Sprague-Dawley rats of both sexes were subjected in the experiment. The rats were 8-10 weeks old, with an average weight of 170.3 $\pm 5.8 \mathrm{gm}$. Every two rats of the same sex were housed in a plastic cage with water and commercial rat pellet ad libitum. A 12-hour dark/light cycle was followed at an ambient temperature of $25^{\circ} \mathrm{C}$.

The rats were left to acclimate for seven days before the commencement of the experiment. The experiment was conducted with the Animal Care and Use Committee's permission at the College of Veterinary Medicine, University of Sulaimani (Approval no. 19/6).

Before the experiment, the rats were divided into four equal groups. The first group served as the control, which was given distilled water by drenching. The other three groups were orally administered with the methanolic extract of $T$. claveryi at dosage rates of 200, 400, and 800 $\mathrm{mg} / \mathrm{kg}$ body weight, respectively. The extract was resuspended in distilled water before being administered once daily for 14 days, using an oral gavage needle. The weights of the animals were recorded at the beginning and end of the experiment. The behaviors of the animals after extract administration were observed daily for up to 30 minutes.

The animals' feed and water intake were measured by weighing the amount of feed and water left after 24 hours and subtracting from the amount initially provided the previous day. Then, the average daily intake of water and feed per group was calculated.

\section{Animal euthanasia and sample collection}

At the end of the experimental duration on day 15, the rats were anesthetized by intraperitoneal injection of a mixture of ketamine $(75 \mathrm{mg} / \mathrm{kg})$ and xylazine $(2 \mathrm{mg} / \mathrm{kg})$. Blood was collected from the caudal vena cava after the abdominal cavity's opening, and placed into two types of tubes. Plain tubes were used for the biochemical analyses of serum, and heparinized tubes were used to collect blood intended for hematological analyses.

The internal organs were inspected for gross pathological changes. The liver, kidneys, spleen, heart, brain, and lungs were washed with normal saline and weighed. The relative organ-to-body weight was measured by dividing the organ's weight by the rat's total weight. The collected organs were processed for histopathological examination

\section{Histopathological examination}

The harvested tissue samples of liver, spleen, kidney, heart, lungs, and brain were fixed in $10 \%$ neutral buffered formalin for 72 hours. After that, the samples were appropriately washed with tap water, dehydrated in ascending alcohol concentrations, cleared in xylene, and embedded in paraffin (6). Five- $\mu$ m-thick tissue sections were obtained using a rotary microtome, stained with hematoxylin and eosin, and examined by different magnifying powers of light microscopy to assess the morphological characteristics of these samples. Histological slides were examined quantitatively by blind analysis. Ten random sections were taken from each slide, and the lesions were scored based on the percentage of affected organ sections as follows; 0: 0-25\%, 1: 26-50\%, 2: 51-75\%, and 3>75\% (7).

\section{Hematological parameters}

Blood samples collected in heparinized tubes were used for the determination of hematological 
parameters. The analyzed parameters were erythrocyte, platelet, and total white blood cell counts, hematocrit, hemoglobin concentration, mean corpuscular hemoglobin $(\mathrm{MCH})$, mean corpuscular hemoglobin concentration (MCHC), and mean corpuscular volume (MCV) using an automated hematology analyzer (Abbott CELLDYN® 3700, USA).

\section{Serum biochemical parameters}

Serum was collected from blood samples in plain tubes by centrifugation of the blood at 3000 revolutions per minute. The samples of sera were analyzed for total protein, albumin, glucose, cholesterol, bilirubin, creatinine, urea, alanine transaminase (ALT), aspartate transaminase (AST), gamma-glutamyl transaminase (GGT), and lactate dehydrogenase (LDH) spectrophotometrically, using an automatic chemistry analyzer (Hitachi 902 Automatic Analyzer) and standard reagents from Roche (Germany).

Statistical analysis

Data were analyzed using a one-way analysis of variance (ANOVA), followed by post hoc (Duncan), using SPSS version 19.0 (IBM, USA). Probability values $<0.05$ were considered statically significant.

\section{Result}

\section{Terfezia claveryi methanolic extract}

The methanolic extraction yielded $18.4 \%$ of the total weight of Terfezia claveryi.

\section{Animal weight and behavioral changes}

All rats treated with the methanolic extract of $T$. claveryi exhibited normal water intake and feeding, compared to the control; there were no differences between the control and treated groups in the amount of feed and water consumption $(\mathrm{P}>0.05)$. No mortality was recorded, and no illness behavioral or signs were observed in the rats throughout treatment. There was no significant difference $(p>0.05)$ in the rate of weight gain between the control and groups treated with $T$. claveryi methanolic extract (Figure $1)$.

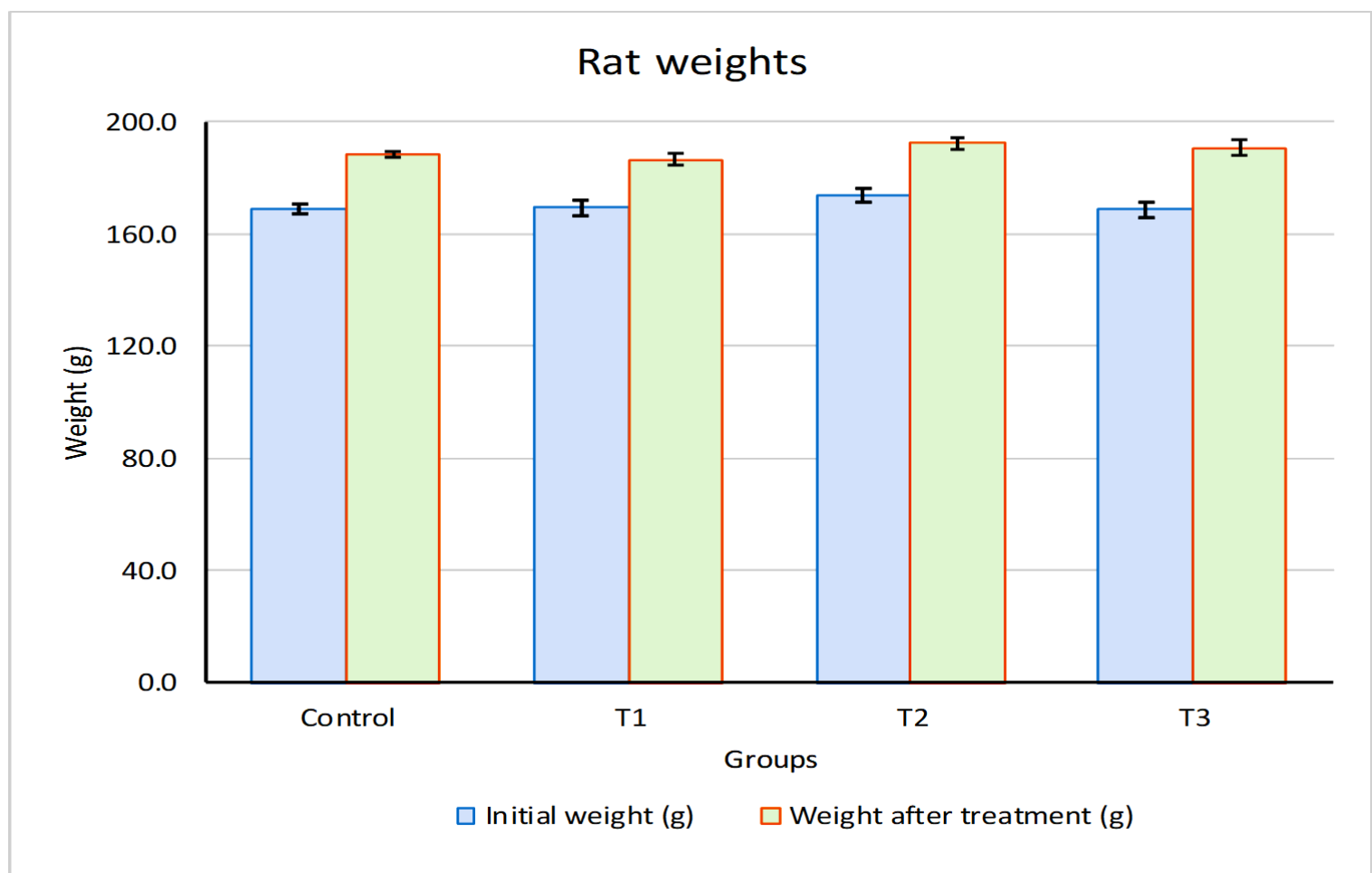

Figure 1. Weight of rats before and after treatment. Values represent the mean of six rats (columns) \pm SEM (error bars). Initial weight $=$ weight of rats before treatment. Weight after treatment $=$ weight of rats after the administration of Terfezia claveryi methanolic extract for 14 days. Control rats administered distilled water. Groups T1, T2, and T3 administered 200,400 , and $800 \mathrm{mg} / \mathrm{kg}$ of $T$. claveryi extract. No significant difference $(p>0.05)$ was seen between the control and different groups on the same day (same-color columns). Statistics = one-way ANOVA (post hoc $=$ Duncan). 


\section{Organ weights and pathological changes}

No abnormalities were observed when the internal organs of the control and treatment groups were grossly examined. Comparing the weights of the heart, liver, kidneys, spleen, lungs, and brain between the treatment groups and the control revealed no significant $(\mathrm{p}>0.05)$ differences. The relative organ-to-body weights also revealed no statistical difference between the experimental groups (Table 1).

Table 1. Organ and relative organ-to-body weights of the experimental groups

\begin{tabular}{|c|c|c|c|c|c|}
\hline \multirow[t]{2}{*}{ Parameter } & & \multicolumn{4}{|c|}{ Group } \\
\hline & & Control & T1 & $\mathrm{T} 2$ & T3 \\
\hline \multirow[t]{6}{*}{ Organ weight (g) } & Heart & $0.83 \pm 0.02$ & $0.78 \pm 0.03$ & $0.82 \pm 0.04$ & $0.77 \pm 0.05$ \\
\hline & Liver & $5.80 \pm 0.26$ & $4.97 \pm 0.51$ & $5.62 \pm 0.34$ & $5.73 \pm 0.43$ \\
\hline & Spleen & $0.77 \pm 0.08$ & $0.77 \pm 0.06$ & $0.75 \pm 0.06$ & $0.71 \pm 0.07$ \\
\hline & Kidneys* & $1.02 \pm 0.05$ & $0.93 \pm 0.03$ & $1.00 \pm 0.04$ & $0.95 \pm 0.05$ \\
\hline & Brain & $1.30 \pm 0.06$ & $1.33 \pm 0.08$ & $1.45 \pm 0.12$ & $1.51 \pm 0.12$ \\
\hline & Lungs & $1.22 \pm 0.06$ & $1.22 \pm 0.05$ & $1.30 \pm 0.10$ & $1.23 \pm 0.05$ \\
\hline \multirow{6}{*}{$\begin{array}{l}\text { Relative organ-to- } \\
\text { body weight }(\%)\end{array}$} & Heart & $0.45 \pm 0.02$ & $0.42 \pm 0.02$ & $0.42 \pm 0.02$ & $0.40 \pm 0.03$ \\
\hline & Liver & $3.07 \pm 0.13$ & $2.67 \pm 0.26$ & $2.92 \pm 0.18$ & $3.02 \pm 0.23$ \\
\hline & Spleen & $0.40 \pm 0.04$ & $0.42 \pm 0.04$ & $0.38 \pm 0.03$ & $0.37 \pm 0.04$ \\
\hline & Kidneys* & $0.53 \pm 0.02$ & $0.50 \pm 0.03$ & $0.53 \pm 0.02$ & $0.48 \pm 0.04$ \\
\hline & Brain & $0.68 \pm 0.03$ & $0.73 \pm 0.04$ & $0.75 \pm 0.07$ & $0.80 \pm 0.05$ \\
\hline & Lungs & $0.63 \pm 0.03$ & $0.65 \pm 0.03$ & $0.67 \pm 0.05$ & $0.67 \pm 0.03$ \\
\hline
\end{tabular}

$*=$ total weight of right and left kidneys.

Values represent the mean of six rats \pm SEM. No significant difference $(p>0.05)$ was present between the different values (within the same row). Statistics = one-way ANOVA (post hoc = Duncan).

The hematological parameters of the different rat groups following the administration of $T$. claveryi methanolic extract are shown in Table 2.

The erythrocytes count was lower in the control group. However, the comparison between the groups revealed no statistical difference $(p>0.05)$. No significant difference was also observed in the hematocrit, hemoglobin, $\mathrm{MCH}, \mathrm{MCHC}, \mathrm{MCV}$, and leukocytes between the different groups

Table 2. Hematological parameters of the experimental groups following administration of Terfezia claveryi methanolic extract

\section{Parameters}

Erythrocytes $\left(\times 10^{12} / \mathrm{L}\right)$

Hematocrit (L/L)

Hemoglobin (g/L)

MCH (pg)

$\operatorname{MCHC}(\mathrm{g} / \mathrm{L})$

MCV (FL)

Leukocytes $(\times 10 \% / L)$

\section{Control}

$5.89 \pm 0.21$

$38.64 \pm 0.46$

$12.78 \pm 0.40$

$19.41 \pm 0.20$

$31.96 \pm 0.33$

$61.39 \pm 0.80$

$5.00 \pm 0.12$

\section{Groups}

T1

$5.92 \pm 0.37$

T2

T3

$6.12 \pm 0.38$

$6.06 \pm 0.35$

$38.38 \pm 0.47$

$38.21 \pm 0.68$

$38.32 \pm 0.40$

$12.88 \pm 0.34$

$12.92 \pm 0.57$

$12.90 \pm 0.60$

$19.20 \pm 0.31$

$19.06 \pm 0.30$

$19.17 \pm 0.15$

$32.32 \pm 0.54$

$32.93 \pm 0.63$

$32.48 \pm 0.54$

$60.13 \pm 0.84$

$59.50 \pm 0.85$

$59.28 \pm 0.52$

$5.34 \pm 0.47$

$5.60 \pm 0.34$

$5.31 \pm 0.35$

Values represent mean of six rats \pm SEM. No significant difference $(p>0.05)$ was present between the different values (within the same row). $\mathrm{MCH}=$ mean corpuscular hemoglobin; $\mathrm{MCHC}=$ mean corpuscular hemoglobin concentration; $\mathrm{MCV}=$ mean corpuscular volume. Statistics = one-way ANOVA (post hoc $=$ Duncan $)$. 
Table 3 shows the mean values of the biochemical constituents of serum taken after 14 days of treatment with $T$. claveryi methanolic extract. Comparing the results between the control and treatment groups showed no significant $\mathrm{p} \leq 0.05$ differences. The concentration of total protein was higher in control $(62.37 \mathrm{~g} / \mathrm{L})$ compared to other groups, but the difference was not statistically significant $(p>0.05)$. Similarly, the control group's urea concentration was $397.33 \pm 25.92$ $\mathrm{mg} / \mathrm{L}$, which was higher than in the treatment groups. However, the difference was not statistically significant.

Table 3. Serological tests of rats treated with Terfezia claveryi methanolic extract

\begin{tabular}{ccccc}
\hline \multirow{2}{*}{ Parameter } & \multicolumn{4}{c}{ Group } \\
\cline { 2 - 5 } & Control & T1 & T2 & T3 \\
\hline Albumin (g/L) & $43.98 \pm 0.72$ & $41.75 \pm 1.24$ & $42.77 \pm 1.07$ & $44.78 \pm 1.45$ \\
\hline ALT (U/L) & $38.62 \pm 2.37$ & $35.20 \pm 3.49$ & $38.12 \pm 3.23$ & $32.41 \pm 4.24$ \\
\hline AST (U/L) & $130.37 \pm 2.08$ & $138.28 \pm 2.61$ & $128.00 \pm 3.11$ & $126.12 \pm 4.21$ \\
\hline Cholesterol (mg/L) & $385.83 \pm 17.55$ & $417.17 \pm 21.44$ & $392.00 \pm 12.59$ & $429.67 \pm 9.92$ \\
\hline Creatinine (mg/L) & $4.80 \pm 0.26$ & $5.42 \pm 0.27$ & $4.95 \pm 0.14$ & $5.17 \pm 0.18$ \\
\hline GGT (U/L) & $45.00 \pm 1.32$ & $42.07 \pm 2.03$ & $45.50 \pm 1.48$ & $42.00 \pm 1.15$ \\
\hline Glucose (mg/L) & $1225.00 \pm 9.61$ & $1269.33 \pm 17.90$ & $1281.50 \pm 20.95$ & $1230.00 \pm 24.63$ \\
\hline LDH (IU/L) & $924.83 \pm 23.29$ & $992.00 \pm 50.09$ & $1004.17 \pm 16.08$ & $955.00 \pm 17.94$ \\
\hline Total bilirubin (mg/L) & $1.27 \pm 0.07$ & $1.17 \pm 0.05$ & $1.40 \pm 0.13$ & $1.22 \pm 0.05$ \\
\hline Total protein (g/L) & $62.37 \pm 1.25$ & $59.10 \pm 1.57$ & $57.82 \pm 2.70$ & $56.50 \pm 2.14$ \\
\hline Urea (mg/L) & $397.33 \pm 25.92$ & $392.33 \pm 24.62$ & $334.32 \pm 19.76$ & $357.67 \pm 24.28$
\end{tabular}

Values represent the mean of six rats \pm SEM. Group T1, T2, and T3 administered 200, 400, and $800 \mathrm{mg} / \mathrm{kg}$ body weight of Terfezia claveryi methanolic extract for 14 days. ALT = alanine transaminase; AST = aspartate transaminase; GGT = gamma-glutamyl transpeptidase; LDH = lactate dehydrogenase. No significant difference $(\mathrm{p}>0.05)$ was present between the different values (within the same row). Statistical analysis used is one-way ANOVA (post hoc = Duncan).

\section{Histopathological findings}

Microscopic examination of the brain, lung, heart, liver, spleen, and kidney samples of rats in the control and treatment groups showed approximately normal histological structure. However, blood vessel congestion was seen in the kidney (Figure 2), liver (Figure 3), and spleen (Figure 4) of rats in the treatment groups receiving 400 and $800 \mathrm{mg} / \mathrm{kg}$ of Terfezia claveryi methanolic extract. Liver congestion was associated with hepatocellular swelling and narrowing of the hepatic sinusoids.

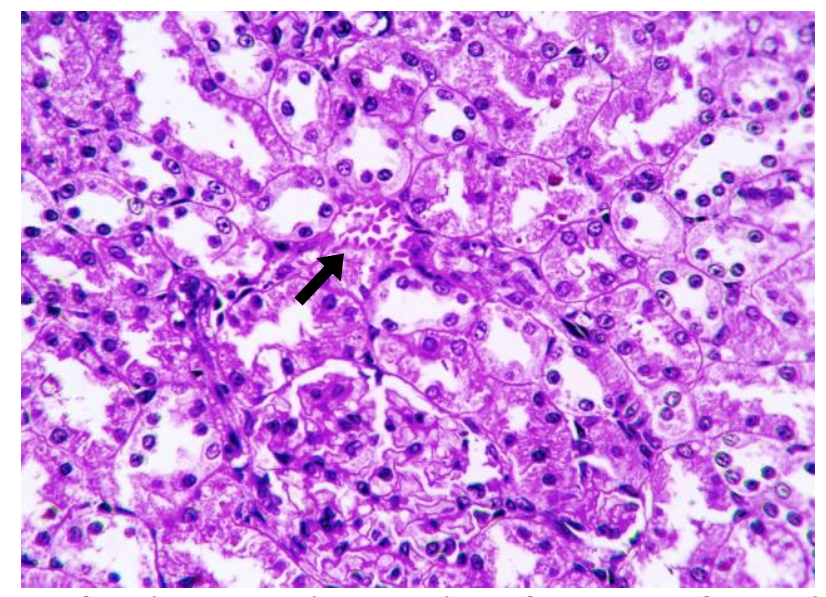

Figure 2. Microscopic view of a kidney section obtained from one of the T2-group animals. It shows the congestion of an interstitial blood vessel (black arrow). H\&E, X400. 


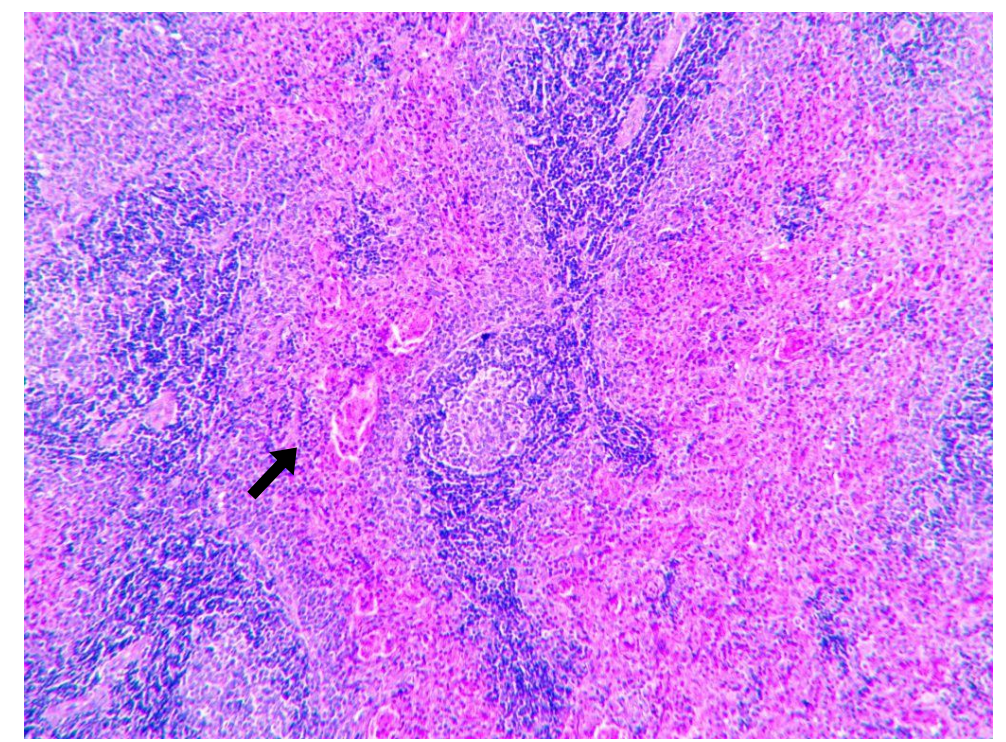

Figure 3. Microscopic view of a spleen section obtained from one of the group T3 animals. It shows red pulp congestion (Black arrow) and white pulp atrophy. H \& E, X200.

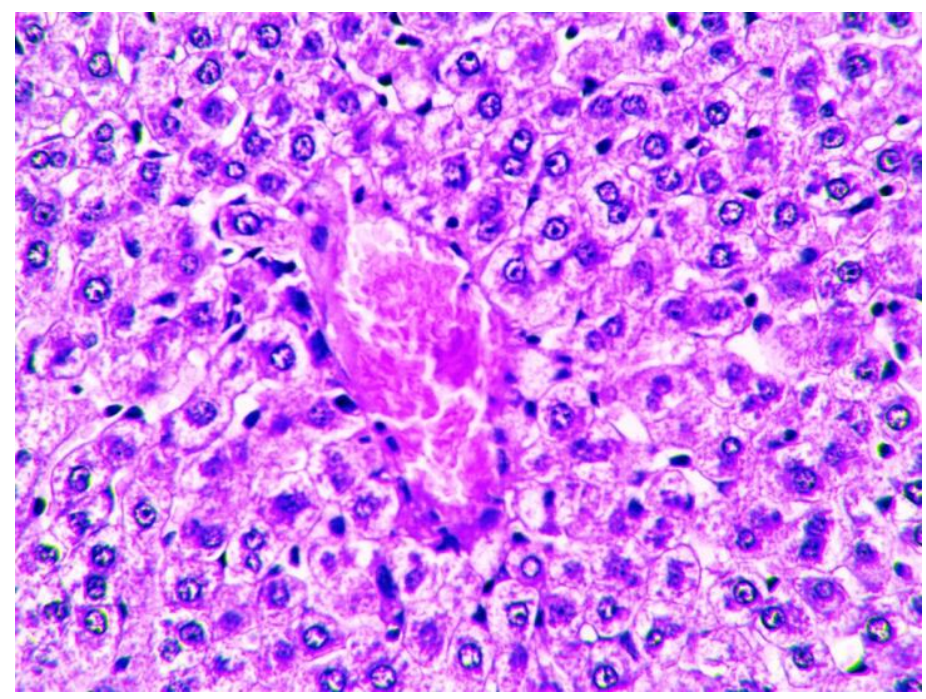

Figure 4. Microscopic view of a liver section obtained from one of the animals in group T3. It shows the congestion of the central vein, hepatocellular swelling, and narrowing of the hepatic sinusoids.

Also, many apoptotic hepatocytes with binucleated cells are observable. H\&E, X400.

\section{Discussion}

The subacute toxicity of Terfezia claveryi methanolic extract was evaluated in this study, using Sprague-Dawley rats as a model. The criteria used included observing behavioral changes following the administration of the extract and measurement of animal and organ weights. Following the rats' sacrifice, hematological and serum biochemical profiles were measured, internal organs were inspected grossly, and histological sections of the heart, liver, kidneys, spleen, lungs, and brain were examined microscopically.
Ideally, toxicological studies of products intended for human consumption should be conducted in humans. However, it is not always possible to test those chemicals in humans. Rats are considered the alternative species of choice for humans because of the many anatomical and physiological similarities between the two species (8).

Illness behavioral changes in animals following the administration of test compounds could indicate these agents' damaging effects on the nervous tissue. Neurotoxic effects should be routinely screened in short-term toxicity studies, and rats are considered the preferred species for 
this purpose (9). In our study, the rats were observed continually for 30 minutes following the administration of $T$. claveryi methanolic extract, and every hour for the first four hours post-administration. The absence of any abnormal behavior after the administration of $T$. claveryi is an indication that the extract did not have detrimental effects on the nervous system of the experimental rats. Examining the brain's histological sections did not show any abnormal lesions in the treated groups' brain tissue, even with the highest dose $(800$ $\mathrm{mg} / \mathrm{kg}$ ) of $T$. claveryi. These results imply that the extract of brown truffle does not have observable neurotoxic effects on SpragueDawley rats. Body and organ weight, body weight gain, and the percentage of organ weights are parameters that should be measured during toxicity studies of chemicals and pharmaceutical compounds (10).

The Society of Toxicologic Pathology recommends organ weights as part of the parameters collected during toxicity studies, as alterations in organ weights are often treatment-related (11). The weights of the rats were recorded before the study and 14 days post-treatment. Furthermore, the liver, kidneys, spleen, heart, brain, and lungs of the test animals were collected and weighed at the end of the experiment. There were no significant differences between the groups regarding body weight, weight gain, organ weights, and relative organ-to-body weights. These results indicate that $T$. claveryi administration to the rats did not cause observable toxicities or reduce the rate of weight gains in these animals. The tissue sections' microscopic examination also indicated that the extract's treatment did not cause degenerative changes in the vital organs' tissue. Although congestion was seen in the kidney, liver, and spleen of rats that administered the higher doses of $T$. claveryi methanolic extract, the lesions were only observed in few sections, and they were not evident in all animals of the same group.

Hematological changes are one of the first to occur following the administration of toxic agents since the hematopoietic system is vulnerable to the toxic effect of chemicals $(\mathbf{1 0}, \mathbf{1 2})$. A comparison of the hematological parameters between the control and treated groups in our study showed that there were no significant differences $(p>0.05)$ between the groups. These results indicated that even with the highest dose $(800 \mathrm{mg} / \mathrm{kg})$, brown truffle did not have any toxic effects on the hematopoietic system or blood parameters.

Several serum biochemical parameters were measured in this study, namely albumin, ALT, AST, cholesterol, creatinine, GGT, glucose, LDH, total bilirubin, total protein, and urea.

These parameters provide information about the status of the different organs and overall body health of the individual.

The liver plays a crucial role in metabolic hemostasis, itis involved in the detoxification of many drugs and xenobiotics, protecting the individual against injury from chemicals (13). It is the first organ that receives ingested nutrients and other absorbed exogenous compounds through the portal vein (14).

Biochemical tests which monitor hepatic integrity can be categorized into tests that screen a) hepatocellular integrity, such as AST and ALT, b) biliary excretory function, such as serum bilirubin and GGT, and c) hepatocyte function, such as measuring of serum albumin and total protein $(\mathbf{1 5}, \mathbf{1 6})$.

Results of serum biochemical tests revealed no significant differences between the different rat groups in the concentrations of serum albumin, AST, ALT, bilirubin, and GGT. These results show that the administration of $T$. claveryi at different concentrations did not have detrimental effects on the hepatocytes or impair hepatic secretory and excretory functions.

The liver primarily regulates blood glucose and cholesterol levels. Therefore, this organ's injury results in the impairment of cholesterol and glucose homeostasis (17).

The serum levels of glucose and cholesterol were measured in our study, and the results revealed no significant differences between the control and treated groups. These results also indicate the no toxic effect of brown truffle on the liver of treated rats.

The kidneys play an essential role in the homeostasis of body fluids and electrolytes via the excretion and reabsorption of solutes 
and water, having a role in regulating blood pressure and regulation of erythrocyte synthesis (18). Serum levels of creatinine and urea are usually monitored to assess renal function (17).

The creatinine and urea levels in T. claveryitreated rats' serum did not differ significantly from the control group rats. These results imply no observable adverse effect of brown truffle's methanolic extract on the treated rats' renal tissue.

No significant difference was observed when the level of LDH was compared between the control and treated groups. LDH is an enzyme that catalyzes the conversion of lactate to pyruvate. It is present in many organs and tissues such as the lungs, liver, kidneys, heart, skeletal muscles, and erythrocytes.

It is routinely measured in toxicity studies since high levels indicate tissue damage (19). Our results indicate that the administration of $T$. claveryi methanolic extract at the highest used dose of $800 \mathrm{mg} / \mathrm{kg}$ did not cause observable tissue damage and, hence, the fungus does not cause tissue toxicity in rats. Administration of brown truffle's methanolic extract did not alter weight gain, organ weights, behavioral changes, and nervous tissue toxicity.

No alterations in hematological parameters and serum biochemistry were observed in the treated rats. Furthermore, the vital organs' histopathological examination did not show noticeable pathological changes in the vital organs. We conclude that the administration methanolic extract of $T$. claveryi did not cause subacute toxicity in Sprague-Dawley rats.

\section{Acknowledgment}

The authors are greatly appreciate the College of Veterinary Medicine at the University of Sulaimani for supportting this study, providing the laboratory facilities required for accomplishing this study.

\section{Conflict of interest}

The authors declare no conflict of interest.

\section{References}

1. Mohammed RS, Ahmed RS, Abdaljalil RO. Uranium, thorium, potassium, and cesium radionuclides concentrations in desert truffles from the governorate of Samawah in Southern Iraq. J Food Prot. 2018; 81(9):1540-1548. Available from: https://doi.org/10.4315/0362-028X.JFP18-138.

2. Marqués-Gálvez JE, Morte A, NavarroRodenas A, Garcia-Carmona F, PerezGilabert M. Purification and characterization of Terfezia claveryi TcCAT-1, a desert truffle catalase upregulated in mycorrhizal symbiosis. PloS One. 2019; 14(7). Available from: https://doi.org/10.1371/journal.pone.0219 300.

3. Schillaci D, Cusimano MG, Cascioferro SM, Di Stefano V, Arizza V, Chiaramonte $\mathrm{M}$, et al. Antibacterial activity of desert truffles from Saudi Arabia against Staphylococcus aureus and Pseudomonas aeruginosa. Int. J. Med. Mushrooms. 2017; 19(2).

4. Khalifa SA, Farag MA, Yosri N, Sabir JS, Saeed A, Al-Mousawi SM, et al. Truffles: From Islamic culture to chemistry, pharmacology, and food trends in recent times. Trends Food Sci. Tech. 2019; 91: 193-218.

5. Al-Laith AAA. Antioxidant components and antioxidant/antiradical activities of desert truffle (Tirmania nivea) from various Middle Eastern origins. J. Food Compos. Anal. 2010; 23(1):15-22. Available from: https://doi.org/10.1016/j. jfca.2009.07.005Get.

6. Bancroft J, Layton C. The hematoxylin and eosin. In: Suvarna SK, Layton C, Bancroft J. Editors. Bancroft's Theory and Practice of Histological Techniques. $7^{\text {th }}$ ed. Amsterdam: Elsevier; 2012. p. 173-186.

7. Stevens A, Lowe JS, Young B, Wheater PR, Burkitt HG, editors. Wheater's basic histopathology: A colour atlas and text. New York: Churchill Livingstone; 2002. $295 \mathrm{p}$. 
8. Johnson MD, Gad SC, Kemper CJ. The rat. In: Gad SC, editor. Animal Models in Toxicology. $3^{\text {rd }}$ edition. New York: CRC Press, Taylor \& Francis Group; 2016. p. 153-284.

9. Food and Drug Administration. Toxicological principles for the safety assessment of food ingredients, iv. C. 3.a. Short-term toxicity studies with rodents [Internet]. Food and Drug Administration; 2003. Available from: https://www.fda.gov/regulatoryinformation/search-fda-guidancedocuments/redbook-2000-ivc3a-shortterm-toxicity-studies-rodents.

10. The Organisation for Economic Cooperation and Development (OECD). Guideline for the testing of chemicals: acute oral toxicity-acute toxic class method. Guideline. [Internet]. The Organisation for Economic Co-operation and Development; 2001. Available from: https://www.oecd-

ilibrary.org/environment/test-no-423acute-oral-toxicity-acute-toxic-classmethod_9789264071001-en.

11. Sellers RS, Mortan D, Michael B, Roome N, Johnson JK, Yano BL, et al. Society of Toxicologic Pathology position paper: organ weight recommendations for toxicology studies. Toxicol Pathol. 2007; 35(5):751-755. Available from: https://doi.org/10.1080/01926230701595 300.

12. Denny KH, Stewart CW. Acute, subacute, subchronic, and chronic general toxicity testing for preclinical drug development. In: Faqi AS, editor. A
Comprehensive Guide to Toxicology in Nonclinical Drug Development. $2^{\text {nd }}$ ed. New York: Elsevier; 2017. p. 109-127.

13. Bischoff $K$, Mukai $M$, Ramaiah SK. Liver toxicity. In: Gupta RC, editor. Veterinary Toxicology: Basic and Clinical Principles. $3^{\text {rd }}$ ed. New York: Elsevier; 2018. p. 239-257.

14. Ramadhan SJ, Khudair KK. Effect of betaine on hepatic and renal functions in acrylamide treated rats. Iraqi .J.Vet.Med. 2019;43: 138-147.

15. Navarro VJ, JR Senior. Drug-related hepatotoxicity. N. Engl. J. Med. 2006;354:731-739.

16. McDaniel MJ. Hepatic Function Testing: The ABCs of the Liver Function Tests. Physician Assist. Clin. 2019;4:541-550.

17. Farkas JD, Farkas P. Liver and gastroenterology tests. In: Lee M, editor. Basic skills in interpreting laboratory data. 4th ed. Maryland: American Society of Health-system Pharmacists; 2009. 618 p.

18. Blaine J, M Chonchol, M Levi. Renal control of calcium, phosphate, and magnesium homeostasis. Clin. J. Am. Soc. Nephrol. 2015;10:1257-1272.

19. Muchtar E, A Dispenzieri, MQ Lacy, FK Buadi, P Kapoor, SR Hayman, W Gonsalves, R Warsame, TV Kourelis, R Chakraborty. Elevation of serum lactate dehydrogenase in AL amyloidosis reflects tissue damage and is an adverse prognostic marker in patients not eligible for stem cell transplantation. Br. J. Haematol. 2017;178:888-895. 
السمية تحت الحادة للكمأ البني (Terfezia claveryi) على جرذان سبراغ داولي

ريبين كانبى مجيد'، ديارى هيوا عثمان" ،"، هرسين محمود رحيم' ، روزه شريف عثمان"، على حسين حسن'

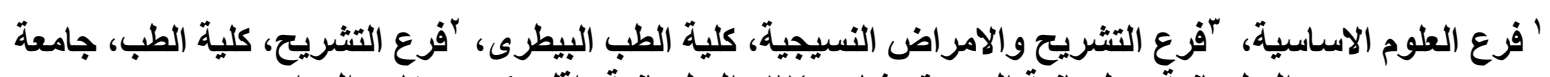

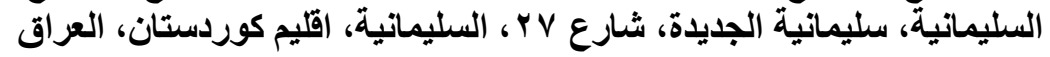

\section{الخلاصة}

الكمأ البني (Terfezia claveryi) هو نوع من الفطريات البرية التي يتم جمعها للاستهلاك البشري في العراق، خاصة خلال

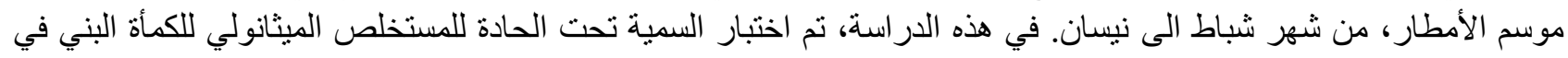

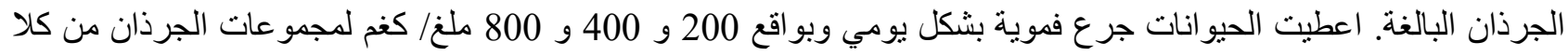

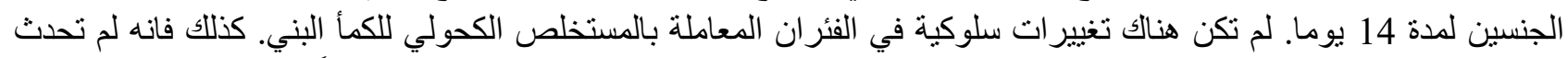

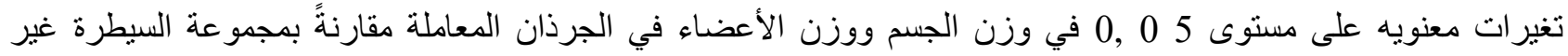

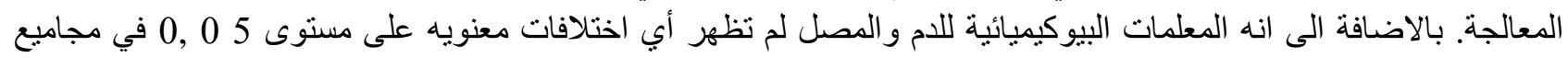

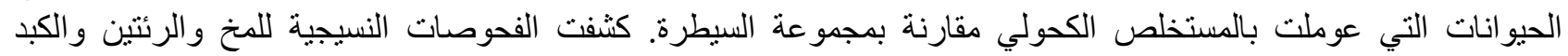

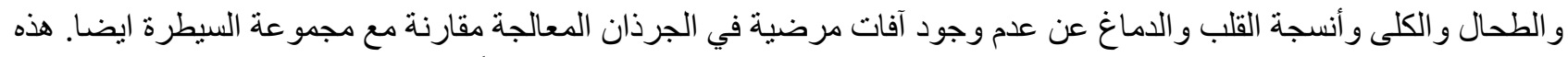

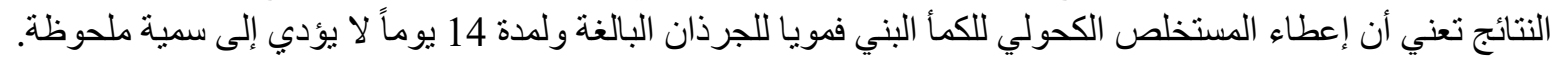
الكلمات المفتاحية: السمية تحت الحادة؛ الكيمياء الحيوية للام؛ فئران سبراغ داولي؛ تيرفيزيا كليفيري. 